\title{
The Relationship of Host Range, Physiology, and Genotype to Virulence on Cantaloupe in Pseudomonas syringae from Cantaloupe Blight Epidemics in France
}

\author{
Cindy E. Morris, Catherine Glaux, Xavier Latour, Louis Gardan, Régine Samson, and Michel Pitrat
}

\begin{abstract}
First, second, and third authors: INRA, Pathologie Végétale, BP 94, 84143 Montfavet, France; fourth and fifth authors: INRA, Pathologie Végétale, BP 57, 49071 Beaucouzé, France, and sixth author: INRA, Génétique et Amélioration des Fruits et Légumes, BP 94, 84143 Montfavet, France.

Current address of X. Latour: Laboratoire de Microbiologie du Froid, IUT Evreux, 55 bd. St. Germain, 27000 Evreux, France. Accepted for publication 11 February 2000.
\end{abstract}

\section{ABSTRACT}

Morris, C. E., Glaux, C., Latour, X., Gardan, L., Samson, R., and Pitrat, M. 2000. The relationship of host range, physiology, and genotype to virulence on cantaloupe in Pseudomonas syringae from cantaloupe blight epidemics in France. Phytopathology 90:636-646.

In 1993, a bacterial blight caused important losses of cantaloupe $(\mathrm{Cu}$ cumis melo var. cantalupensis) in southwestern France and has now been reported in all cantaloupe-growing regions of France. The causal agent of this blight is Pseudomonas syringae, although on a worldwide basis this bacterium has not been a major pathogen of melon for over 50 years. To identify the pathovar of the cantaloupe pathogen, we employed biochemical tests, plasmid and chromosomal profiling, and host range studies for
23 strains from cantaloupe and 47 reference strains of 14 pathovars of $P$. syringae. Numerical analysis of 119 traits, serological typing, syringomycin production, and BOX-polymerase chain reaction profiles did not allow us to differentiate among pathovars related to $P$. syringae pv. syringae. Host range studies of cantaloupe and references strains on 18 plant species showed that virulence to sugar beet was a common feature of strains virulent on cantaloupe, but was not common to strains avirulent on cantaloupe. Virulence to other species of plants varied among strains, but the overall extent of the host range was proportional to aggressiveness to cantaloupe. We propose that the strains attacking cantaloupe in France be considered $P$. syringae pv. aptata and that adequate host range testing may reveal that this pathovar is the cause of cantaloupe blight reported in other parts of the world.
France produces about 300,000 tons of cantaloupe (Cucumis melo L. var. cantalupensis Naudin) annually on about 15,000 ha situated in the southwest, central west, and southeast regions. In 1993, a severe bacterial blight led to important losses of cantaloupe in the Tarn-et-Garonne region of southwestern France. Since 1993, bacterial blight has been reported in all major cantaloupe-growing regions of France in the southwest and central west (23) and just recently in the southeast. Disease symptoms include necrotic leaf spots that may be encircled by water-soaked halos, stem and petiole cankers, and sunken lesions on fruits that may be accompanied by large, dryrotted cavities in the flesh of the fruit. Epidemics occurring at the time of early fruit development can lead to fruit drop. In 1996 and 1997, when the severest epidemics were observed, up to $80 \%$ of the production fields in the southwest were infected and some growers reported $100 \%$ yield losses due to bacterial blight (23). Although numerous viral and fungal diseases are common in commercial production fields of cantaloupe in France, no bacteria have been previously reported to cause serious disease problems (4).

On a worldwide basis, seven species of bacteria have been reported to be pathogenic to $C$. melo. Acidovorax avenae subsp. citrulli, a pathogen of watermelon, has caused important damage to fruit of honeydew melon (C. melo var. inodorus) in Texas (13). Erwinia tracheiphila causes bacterial wilt, which is one of the most devastating diseases of muskmelon (C. melo var. cantalupensis), in the midwestern and eastern United States (29). This disease also occurs in Asia (29), but is uncommon in Europe (30). Xanthomonas melonis causes soft rots of melon fruits in produc-

Corresponding author: C. E. Morris; E-mail address: morris@avignon.inra.fr

Publication no. P-2000-0417-01R

(C) 2000 The American Phytopathological Society tion fields in Brazil (24). C. melo is listed among the host plants of $X$. cucurbitae (6), but there are few reports about the importance of this bacterium on melons. Pseudomonas viridiflava has recently been reported to cause leaf blight of melon (variety not specified) in Greece (9). None of these bacteria have been reported to attack cantaloupe in France. E. carotovora subsp. carotovora probably occurs in most melon-growing regions where warm and humid conditions prevail. In France, this pathogen seems to be more important when plants are cultivated under plastic tunnels than in open fields (4). Several reports have suggested that $P$. syringae is also pathogenic to melons, but it is not clear which pathovars have this capacity. Blancard et al. (4) reported that $P$. syringae occasionally causes damage in the greenhouse and plastic tunnel production of cantaloupe near Almeria, Spain. However, no strains are available for the determination of pathovar identity. Smith (31) attributed sunken spots on honeydew fruit to $P$. syringae pv. lachrymans. In that study, the pathovar was identified on the basis of biochemical tests, but not on host range. A strain of $P$. syringae isolated from $C$. melo in New Zealand was identified as $P$. syringae pv. syringae based on biochemical tests, DNA-DNA homology, and pathogenicity to lilac (39). That author suggests that $C$. melo is a previously unreported host for $P$. syringae pv. syringae. However, he did not confirm the pathogenicity of his strain on $C$. melo or report the host range of this strain.

Although the pathovar identity of the few strains of $P$. syringae that are pathogenic on melons is debatable, over the past 50 years this species of bacterium apparently has not been an important pathogen of $C$. melo. However, in a preliminary study, we have determined that $P$. syringae is the causal agent of the severe cantaloupe blight that is widespread in France (23). The objective of this work was to characterize the population of $P$. syringae attacking cantaloupe in France and determine which pathovar(s) is(are) responsible for this new disease outbreak. To identify the patho- 
var, we employed biochemical and physiological tests, plasmid and chromosomal profiling, and extensive host range studies.

\section{MATERIALS AND METHODS}

Bacterial strains and culture conditions. Strains of bacteria pathogenic to cantaloupe were isolated from lesions on leaves, stems, and fruits and from seeds of fruits harvested from commercial production fields. Plant tissues were washed under running tap water for a few seconds and patted dry with clean paper towels. The zone of chlorotic or green tissues at the margin of lesions was aseptically excised and placed directly on plates of King's medium B (KB) (16) containing cycloheximide $(50 \mathrm{mg} / \mathrm{liter})$ or on plates of tryptic soy agar (TSA) (1.7 g of tryptone, $0.3 \mathrm{~g}$ of Bacto-Soytone, $0.25 \mathrm{~g}$ of glucose, $0.5 \mathrm{~g}$ of $\mathrm{NaCl}, 0.5 \mathrm{~g}$ of $\mathrm{K}_{2} \mathrm{HPO}_{4}, 15 \mathrm{~g}$ of agar, and $50 \mathrm{mg}$ of cycloheximide per liter). Excised tissue was also macerated in sterile distilled water, and this macerate was streaked onto KB and TSA (Difco Laboratories, Detroit). Seeds collected from diseased fruits were placed directly on plates of culture media. After incubation of the plates for 2 to 4 days at $25^{\circ} \mathrm{C}$, bacterial growth was streaked for single clones on KB and TSA. Pure strains of the bacteria isolated from lesions and seeds were tested for induction of a hypersensitive response in tobacco by infiltrating fully developed leaves of Nicotiana tabacum L. cv. Samsun plants at the 10-leaf stage with bacterial suspensions of 48-h-old cultures at approximately $1 \times 10^{8} \mathrm{CFU} / \mathrm{ml}$ (17). Strains of bacteria that induced the hypersensitive response in plants within $48 \mathrm{~h}$ of incubation at $25^{\circ} \mathrm{C}$ were further characterized for their biochemical and physiological properties and for their pathogenicity to cantaloupe and other plant species. Origins of bacterial strains isolated from and pathogenic to cantaloupe used in this study are listed in Table 1.

Strains of bacteria obtained from culture collections are listed in Table 2. All strains were cultured once on $\mathrm{KB}$ and then stored in $20 \%$ glycerol at $-80^{\circ} \mathrm{C}$ and in sterile potassium phosphate buffer (6.75 $\mathrm{g}$ of $\mathrm{KH}_{2} \mathrm{PO}_{4}$ and $8.75 \mathrm{~g}$ of $\mathrm{K}_{2} \mathrm{HPO}_{4}$ per liter, $\mathrm{pH} 7$ ) at $4^{\circ} \mathrm{C}$.

Biochemical and physiological tests. Production of fluorescent pigment; presence of arginine dihydrolase, oxidase, gelatinase, levan sucrase, and Tween esterase; and reduction of nitrate and hydrolysis of esculin were tested according to Lelliott et al. (19). Pectinolytic activity was tested according to the method of Prunier and Kaiser (27) and on pectate gels at $\mathrm{pH} 5$ and $\mathrm{pH} 8$ (12). Utilization of DLlactate, L-leucine, $\mathrm{L}(+)$ tartrate, and $\mathrm{D}(-)$ tartrate was tested in the basal medium of Stanier et al. (32) containing phenol red (0.01 g/liter). Utilization of sucrose, sorbitol, erythritol, and mannitol was tested according to Young (39). Presence of DNase was tested on DNAgar (BioMérieux, La Balme-les-Grottes, France). Assimilation of an additional 99 carbon sources was tested with Biotype-100 plates (BioMérieux) that were incubated at $25^{\circ} \mathrm{C}$. Growth was recorded after 4 days. Production of syringomycin was evaluated on potato dextrose agar and on syringomycin minimal medium (SRM) (10) according to the bioassay of Gross and DeVay (11), using a laboratory strain of Geotrichum candidum as the indicator organism. The distance between the border of the bacterial colony and the edge of the fungal lawn (zone of inhibition) was measured after 3 and 6 days of incubation.

Numerical taxonomy. Cluster analysis was performed on a database of 119 characteristics (99 carbon sources from the Biotype100 plates, 9 additional carbon sources, 9 tests for enzyme activities, fluorescent pigment production on $\mathrm{KB}$, and induction of a hypersensitive response in tobacco) as described by Gardan et al. (8). Data for reference strains not characterized in this study were taken from Gardan et al. (8). Calculations were performed with the TAXONUM program produced by G. Hunault (Faculté des Sciences, Angers, France) and L. Gardan.

Serological characterization. The serotype of cantaloupe strains was determined according to the methods used by Saunier et al. (28) to identify $23 \mathrm{O}$-serogroups of $P$. syringae. Antisera were produced in rabbits by injecting whole-cell bacteria intravenously.
Bacteria were grown in yeast peptone broth $(0.3 \%$ yeast extract and $0.5 \%$ peptone) for $24 \mathrm{~h}$, washed, and then resuspended at a concentration of $1 \times 10^{8}$ cells per $\mathrm{ml}$ in sterile phosphate buffer containing $0.5 \%$ formalin (28). Serological reactions were determined by Ouchterlony double-diffusion, using dense bacterial suspensions in distilled water $\left(1 \times 10^{10}\right.$ cells per $\left.\mathrm{ml}\right)$ and raw antisera. Lipopolysaccharide-antibody precipitate appeared as a unique band, showing total or partial identity with serological references.

Repetitive sequence-based-polymerase chain reaction (repPCR) fingerprinting. Characterization of genomic DNA was based on PCR using primers for the BOX element. BOX-PCR analysis was conducted for all strains isolated from cantaloupe and for reference strains from pathovars having strains that caused compatible reactions on cantaloupe. Primer sequences (obtained from Genset SA, Paris, France) were as described by Versalovic et al. (36). PCR amplifications were performed with a model 480 Thermal Cycler (Perkin-Elmer, Norwalk, CT) using the cycles described by Louws et al. (20): 1 initial cycle at $95^{\circ} \mathrm{C}$ for $7 \mathrm{~min}$; 30 cycles of denaturation at $94^{\circ} \mathrm{C}$ for $1 \mathrm{~min}$, annealing at $5^{\circ} \mathrm{C}$ for $1 \mathrm{~min}$, and extension at $65^{\circ} \mathrm{C}$ for $8 \mathrm{~min}$; followed by a single final extension cycle at $65^{\circ} \mathrm{C}$ for $15 \mathrm{~min}$ and a final soak at $4^{\circ} \mathrm{C}$. Template DNA consisted of suspensions of cells treated with $0.5 \mathrm{M} \mathrm{NaOH}$ for $15 \mathrm{~min}$ at $95^{\circ} \mathrm{C}$. One microliter of cell suspension was added to each $24-\mu \mathrm{l}$ aliquot of reaction mixture, which contained $50 \mathrm{pmol}$ of the primer, $1.25 \mathrm{mM}$ deoxynucleoside triphosphate, and $2 \mathrm{U}$ of BioTaq DNA polymerase (Quantum Bioprobe, Montreuil-sous-Bois, France). Reaction mixtures were overlaid with $25 \mu$ of sterile mineral oil before amplification. PCR products were analyzed by horizontal electrophoresis at room temperature in $11 \times 14-\mathrm{cm}$ gels $(1.5 \%$ agarose) in Tris-acetate-EDTA buffer (TAE; $40 \mathrm{mM}$ Tris, $4 \mathrm{mM}$ sodium acetate, and $1 \mathrm{mM}$ EDTA) at $100 \mathrm{~V}$ for $105 \mathrm{~min}$. Gels were stained with ethidium bromide, rinsed in TAE buffer, and photographed under UV light $(612 \mathrm{~nm})$ with a digital camera.

Plasmid profiles. Bacterial strains were grown for $24 \mathrm{~h}$ at $25^{\circ} \mathrm{C}$ in liquid $\mathrm{KB}$ (without cycloheximide). The cells were pelleted by centrifugation $(8,000 \times g$ for $3 \mathrm{~min})$, suspended in sterile water, and adjusted to an absorbance value at $620 \mathrm{~nm}\left(A_{620}\right)$ of 1.0. Plasmids were isolated and detected by gel electrophoresis according to the method of Kado and Liu (15) with the modifications described by Latour et al. (18).

Pathogenicity tests. The virulence of reference strains and strains isolated from cantaloupe was determined on 18 species of plants from eight families: onion (Allium cepa L. cv. Jaune Paille), sugar

TABLE 1. Strains of Pseudomonas syringae used in this study that were isolated from and pathogenic to cantaloupe

\begin{tabular}{lccll}
\hline Strain & Year isolated & Organ of origin & & \multicolumn{1}{c}{ Location collected } \\
\hline CC01 & 1995 & Leaf & Tarn-et-Garonne, France \\
CC04 & 1995 & Leaf & Tarn-et-Garonne, France \\
CC05 & 1995 & Leaf & Tarn-et-Garonne, France \\
CC09 & 1995 & Fruit & Tarn-et-Garonne, France \\
CC23 & 1996 & Leaf & Agadir, Morocco \\
CC40 & 1996 & Fruit & Tarn-et-Garonne, France \\
CC43 & 1996 & Seed & Tarn-et-Garonne, France \\
CC62 & 1997 & Leaf & Tarn-et-Garonne, France \\
CC66 & 1997 & Fruit & Gers, France \\
CC70 & 1997 & Leaf & Tarn-et-Garonne, France \\
CC73 & 1997 & Leaf & Lot, France \\
CC74 & 1997 & Leaf & Tarn-et-Garonne, France \\
CC84 & 1997 & Stem & Tarn-et-Garonne, France \\
CC85 & 1997 & Leaf & Gard, France \\
CC88 & 1997 & Fruit & Tarn-et-Garonne, France \\
CC94 & 1997 & Leaf & Tarn-et-Garonne, France \\
CC101 & 1997 & Leaf & Tarn-et-Garonne, France \\
CC103 & 1997 & Leaf & Gers, France \\
CC111 & 1997 & Leaf & Lot, France \\
CC125 & 1997 & Leaf & Lot, France \\
CC145 & 1997 & Leaf & Lot-et-Garonne, France \\
CC159 & 1997 & Leaf & Charente-Maritime, France \\
CC164 & 1997 & Petiole & Charente-Maritime, France \\
\hline
\end{tabular}


beet (Beta vulgaris L. var. rapa cv. Sucrière), sunflower (Helianthus annuus L.), lettuce (Lactuca sativa L. cv. Mantila), Chinese cabbage (Brassica pekinense (Lour.) Rupr. cv. 106), melon (C. melo L. var. cantalupensis Naudin cv. Védrantais), cucumber (C. sativus L. cv. Marketer), winter wheat (Triticum aestivum L. cv. Soisson), oats (Avena sativa L.), corn (Zea mays L. cv. Epi d'Or), barley (Hordeum vulgare L.), sorghum (Sorghum bicolor (L.) Moench cv. Argence), soybean (Glycine max (L.) Merr. cv. Paoki), pinto bean (Phaseolus vulgaris L. cv. Pinto), pea (Pisum sativum L. cv. Douce Provence), tomato (Lycopersicon esculentum Mill. cv. Monalbo), pepper (Capsicum annuum L. cv. Yolo Wonder), and eggplant (Solanum melongena L. cv. Violette). Dicotyledonous plants were inoculated at the two-leaf stage (two trifoliate leaves for bean plants), except peas, which were inoculated at the four-leaf stage. Monocotyledonous plants were inoculated at the two- to three-leaf stage. Inoculum consisted of aqueous suspensions of 48-h-old bacterial cultures from KB plates adjusted to an $A_{620}$ of 0.3 (approximately $1 \times 10^{8} \mathrm{CFU} / \mathrm{ml}$ ). An aliquot of approximately $50 \mu \mathrm{l}$ of each bacterial suspension was injected into the petiole of the oldest leaf (second leaf for peas) near the junction of the petiole and leaf blade. For each strain, three plants of each species (except cantaloupe) were inoculated in a first experiment conducted from February to June 1998 and an additional three plants were inoculated in a second experiment conducted from May to September 1998. For cantaloupe, each strain was inoculated on 11 plants planted at 11 different dates between February and September 1998 (one plant per date). Plants were incubated for 7 days in plastic chambers in the greenhouse to assure high relative humidity. The reaction of the plant was scored at 2 and 7 days after inoculation as 0 (no obvious symptoms), 1 (hypersensitive-like reaction localized at the point of inoculation), 2 (slight expansion of a necrotic zone of tissue away from the point of inoculation, necrosis and breaking of the petiole, or both), or 3 (expansion of a necrotic zone of tissue away from the point of inoculation, leading to death of the entire leaf or the entire plant). Bacteria were reisolated from selected plants to confirm that symptoms were caused by the pathogen. For all plants other than cantaloupe, the pathogenicity of the bacterial strain was defined in terms of the consistency of the response between the two inoculation dates. Strains were considered to be virulent on a given plant species if at least two of the three

TABLE 2. Reference strains of pathovars of Pseudomonas syringae used in this study

\begin{tabular}{|c|c|c|c|c|}
\hline Pathovar or group & Strain & Host of origin & Location collected & Source \\
\hline pv. aceris & 2339 type strain & Acer sp. & United States & $\mathrm{CFBP}^{\mathrm{a}}$ \\
\hline \multirow{2}{*}{ pv. antirrhini } & 1620 pathotype & Antirrhinum majus & United Kingdom & CFBP \\
\hline & 1723 & Antirrhinum majus & Australia & CFBP \\
\hline \multirow[t]{4}{*}{ pv. aptata } & 1617 type strain & Beta vulgaris & United States & CFBP \\
\hline & 1906 & Beta vulgaris & France & CFBP \\
\hline & 2280 & Beta vulgaris & France & CFBP \\
\hline & 2471 & Beta vulgaris & The Netherlands & CFBP \\
\hline & 1629 & Unknown & Unknown & CFBP \\
\hline & 2213 type strain & Triticum aestivum & New Zealand & CFBP \\
\hline & 2256 & Triticum aestivum & Greece & CFBP \\
\hline pv. cannabina & 2341 type strain & Cannabis sativus & Hungary & CFBP \\
\hline pv. garcae & 1634 type strain & Coffea arabica & Brazil & CFBP \\
\hline pv. japonica & 2896 & Hordeum vulgare & Japan & CFBP \\
\hline pv. lachrymans & 70 & Cucumis sativus & France & CFBP \\
\hline & 3322 & Unknown & Unknown & CFBP \\
\hline pv. panici & 2345 type strain & Panicum sp. & United States & CFBP \\
\hline \multirow[t]{3}{*}{ pv. papulans } & 1748 & Malus sylvestris & United States & CFBP \\
\hline & 1754 type strain & Malus sylvestris & Canada & CFBP \\
\hline & 3326 & Malus pumila & United States & CFBP \\
\hline \multirow[t]{2}{*}{ pv. pisi } & 1436 & Pisum sativum & France & CFBP \\
\hline & 2258 & Pisum sativum & France & CFBP \\
\hline pv. primulae & 1660 type strain & Primula sp. & United States & CFBP \\
\hline \multirow[t]{8}{*}{ pv. syringae } & 1019 & Prunus domestica & France & CFBP \\
\hline & 1392 type strain & Syringa vulgaris & United Kingdom & CFBP \\
\hline & 1583 & Prunus persica & France & CFBP \\
\hline & 1608 & Rosa sp. & France & CFBP \\
\hline & 1679 & Piper nigrum & Brazil & CFBP \\
\hline & 1693 & Sorghum vulgare & Yugoslavia & CFBP \\
\hline & B728a & Phaseolus vulgaris & United States & S. S. Hirano \\
\hline & 3390 & Cucurbita maxima & New Zealand & ICMP \\
\hline Not specified & Grisp 322 & Cucumis melo & France & CFBP \\
\hline
\end{tabular}

${ }^{a}$ Collection Française de Bactéries Phytopathogènes (CFBP), INRA, Pathologie végétale et Phytobactériologie, BP 57, 49071 Beaucouzé, France. L. Gardan, curator.

${ }^{\mathrm{b}}$ International Collection of Microorganisms from Plants (ICMP), Landcare Research New Zealand Limited, Private Bag 92 170, Mt. Albert, Auckland, New

Zealand. J. Young, curator.

${ }^{\mathrm{c}}$ University of Wisconsin, Madison, WI. 
plants inoculated showed a compatible response (disease scores of 2 or 3 ) at both dates. Likewise, strains were considered to induce either hypersensitive-like reactions or no apparent reaction if at least two of three plants had a score of 1 or 0 , respectively, in both blocks. Strains were considered virulent on cantaloupe if at least 7 of 11 plants showed a compatible reaction.

TABLE 3. Syringomycin production by reference strains of Pseudomonas syringae and by strains from cantaloupe

\begin{tabular}{lll}
\hline & \multicolumn{2}{l}{ Zone of inhibition $(\mathrm{mm})^{\mathrm{a}}$} \\
\cline { 2 - 3 } Strain & PDA & SRM
\end{tabular}

Strains from cantaloupe

\begin{tabular}{|c|c|c|}
\hline CCO1 & & \\
\hline CC01 & 13 & 12 \\
\hline $\mathrm{CC} 04$ & 6 & 3 \\
\hline $\mathrm{CC} 09$ & 6 & 11 \\
\hline $\mathrm{CC} 23$ & 8 & 9 \\
\hline $\mathrm{CC} 40$ & 0 & 7 \\
\hline $\mathrm{CC} 43$ & 9 & 7 \\
\hline CC62 & 0 & 7 \\
\hline CC66 & 0 & 0 \\
\hline $\mathrm{CC} 70$ & 1 & 10 \\
\hline $\mathrm{CC} 73$ & 0 & 0 \\
\hline $\mathrm{CC} 74$ & 5 & 9 \\
\hline CC84 & 0 & 7 \\
\hline CC85 & 4 & 7 \\
\hline CC88 & 0 & 1.5 \\
\hline CC94 & 0 & 1 \\
\hline CC101 & 0 & 2 \\
\hline $\mathrm{CC} 103$ & 0 & 8 \\
\hline $\mathrm{CC} 111$ & 9 & 7 \\
\hline $\mathrm{CC} 125$ & 0 & 7 \\
\hline $\mathrm{CC} 145$ & 0 & 5 \\
\hline CC159 & 0 & 0 \\
\hline CC164 & 5 & 11 \\
\hline \multicolumn{3}{|l|}{ eference strains } \\
\hline P. syringae pv. aptata 1617 & 4 & Not determined \\
\hline P. syringae pv. aptata 1906 & 0 & 8 \\
\hline P. syringae pv. atrofaciens 2213 & 11 & 7 \\
\hline P. syringae pv. atrofaciens 2256 & 19 & 20 \\
\hline P. syringae pv. syringae 1392 & 5 & 0 \\
\hline P. syringae pv. syringae 1780 & 0 & 0 \\
\hline P. syringae pv. syringae 1788 & 0 & 0 \\
\hline$P$. syringae pv. syringae 5B530 & 12 & 9 \\
\hline P. syringae pv. syringae $\mathrm{B} 728 \mathrm{a}$ & 8 & 1.2 \\
\hline P. syringae pv. syringae 9B1 & 0 & 1 \\
\hline
\end{tabular}

${ }^{a}$ Values represent the mean width of inhibition zones for two replicates measured at 6 days after inoculation of the indicator fungus. Inhibition was determined on potato dextrose agar (PDA) and on syringomycin minimal medium (SRM) (10).

\section{RESULTS}

Biochemical and physiological characteristics. All strains produced fluorescent pigment on KB; hydrolyzed gelatin and esculin; used DL-lactate as a carbon source; gave negative reactions for the oxidase, arginine dihydrolase, and pectolytic enzyme tests; and induced distinct hypersensitive reactions in tobacco leaves within 24 to $48 \mathrm{~h}$ after inoculation. Production of levan was positive for $74 \%$ of the strains. Of the 23 strains tested, five, four, and none used $\mathrm{D}(-)$ tartrate, L(+)tartrate, and L-leucine, respectively, as single carbon sources. All strains, except CC66, CC73, and CC159, inhibited the growth of $G$. candidum on agar medium (Table 3). Zones of inhibition ranged from 1 to $13 \mathrm{~mm}$ wide. Strains of $P$. syringae from cantaloupe were similar to strains of $P$. syringae pvs. aptata, atrofaciens, japonica, and syringae based on their reactions in the lactate, gelatin, esculin, pectolytic enzyme, and syringomycin tests according to the results published by Young and Triggs (40) for pathovars of $P$. syringae. However, only a few of the cantaloupe strains used $\mathrm{D}(-)$ tartrate, whereas $80 \%$ of the $P$. syringae pv. aptata strains tested by Young and Triggs (40) used this carbon source. Furthermore, none of the cantaloupe strains used L-leucine, whereas about 50 to $80 \%$ of the strains of $P$. syringae pvs. atrofaciens, japonica, and syringae tested by Young and Triggs (40) used this substrate.

Numerical taxonomy. The dendrogram displaying the distance relationships of 98 strains (85 reference strains and 13 cantaloupe strains) based on numerical analysis of 119 traits is shown in Figure 1. Data for 38 of the reference strains was taken from Gardan et al. (8). At a distance of 0.17 (similarity $=83 \%$ ), 9 phena and 39 unique strains were differentiated. Phenon 1 included all 13 cantaloupe strains as well as strains of $P$. syringae pvs. aceris, aptata, atrofaciens, lapsa, panici, papulans, primulae, and syringae. However, strains of $P$. syringae pvs. aptata, primulae, and syringae were also found in other phena. The biochemical characteristics that differentiate phenon 1 from the other main phena identified by numerical analysis are presented in Table 4 .

Serological properties. Serogroups were determined for the 23 cantaloupe strains. Eleven strains belonged to the APTPIS O-serogroup of Saunier et al. (28), nine strains were scattered into six different O-serogroups, and three strains belonged to none of the 23 O-serogroups tested (Table 5). The serogroup of a strain was not related to its geographic origin or date of isolation.

Chromosome and plasmid profiles. Plasmids were detected in only 1 of the 18 strains of $P$. syringae isolated from cantaloupe that were examined. Strain CC85 harbored one plasmid of $60 \mathrm{~kb}$.

TABLE 4. Biochemical characteristics that differentiate phenon 1, containing cantaloupe strains, from phena 2 to 9 and from strains CFBP 2280 and CFBP $2896^{a}$

\begin{tabular}{|c|c|c|c|c|c|c|c|c|c|c|c|}
\hline \multirow{2}{*}{$\begin{array}{l}\text { Biochemical } \\
\text { characteristic }\end{array}$} & \multicolumn{9}{|c|}{ Phenon } & \multicolumn{2}{|c|}{ Strain } \\
\hline & 1 & 2 & 3 & 4 & 5 & 6 & 7 & 8 & 9 & CFBP 2280 & CFBP 2896 \\
\hline Esculin & $+^{\mathrm{b}}$ & + & + & + & + & 80 & - & - & - & + & + \\
\hline Betain & + & + & + & + & + & + & + & 75 & + & + & - \\
\hline Erythritol & + & - & 50 & + & + & + & - & - & + & + & - \\
\hline DL-lactate & + & - & 50 & - & 50 & - & - & 25 & - & + & - \\
\hline Trigonelline & 87 & + & + & - & + & + & + & + & + & + & + \\
\hline $\mathrm{L}(+)$ tartrate & - & 25 & 50 & - & - & 80 & - & + & + & - & - \\
\hline Malonate & + & + & - & 80 & + & 80 & + & + & - & - & + \\
\hline Transaconitate & + & + & + & + & + & 80 & - & 50 & + & + & + \\
\hline L-histidine & 87 & + & + & - & + & + & + & + & + & - & + \\
\hline DL- $\beta$-hydroxybutyrate & 72 & - & - & 40 & - & + & + & 50 & - & - & + \\
\hline Caprylate & + & + & - & 60 & + & + & + & + & 50 & - & + \\
\hline Caprate & 84 & 75 & - & 60 & + & + & + & + & 50 & - & + \\
\hline $\mathrm{D}(-)$ tartrate & 39 & + & + & 20 & + & 80 & + & 50 & 50 & - & - \\
\hline Propionate & 57 & 75 & - & 60 & + & 60 & - & - & + & - & - \\
\hline Putrescine & 27 & - & - & - & + & + & + & - & - & - & - \\
\hline L-tyrosine & - & 25 & - & - & + & 60 & + & - & - & - & - \\
\hline Saccharose & + & + & + & + & - & + & + & 75 & 50 & + & + \\
\hline
\end{tabular}

a The strains in each of these phena are listed in Figure 1.

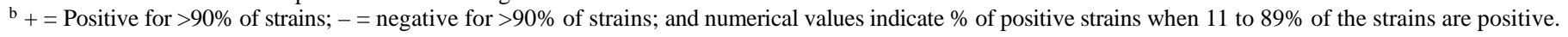




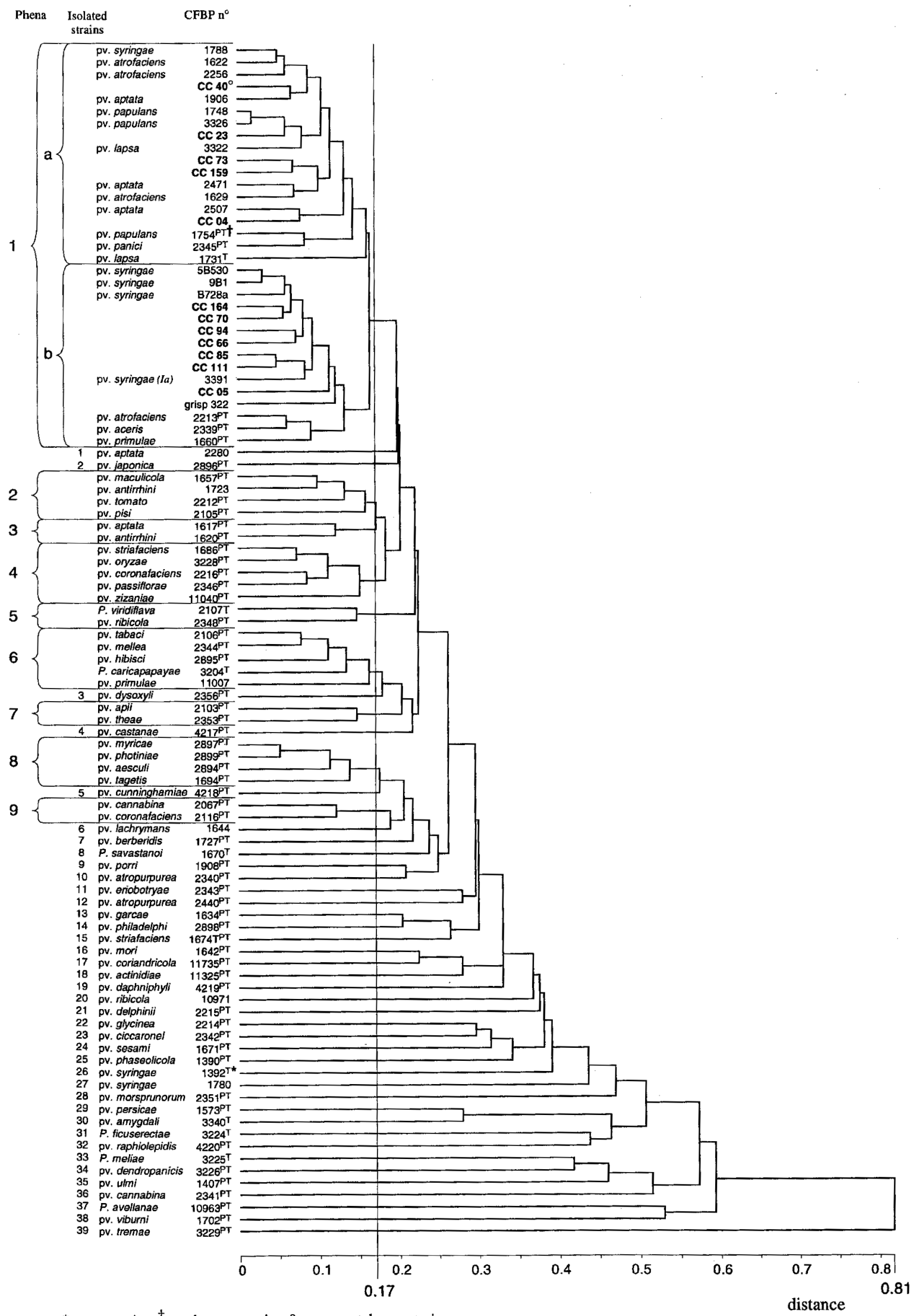

$*$, type strain ${ }^{\dagger}$, pathotype strain $;^{\circ}, \mathrm{cc}=$ cantaloupe strain.

Fig. 1. Dendrogram of the distances among 98 strains of Pseudomonas syringae. The dendrogram includes 13 strains from cantaloupe described in Table 1 and 28 reference strains described in Table 2. The remaining strains are all from the Collection Française de Bactéries Phytopathogènes (cf. 8). The data for biochemical and physiological properties of these strains are presented by Gardan et al. (8). 
Reference strains of $P$. syringae pvs. cannabina, garcae, lachrymans, and pisi all contained two to seven plasmids per strain having sizes of 12 to $300 \mathrm{~kb}$. Reference strains of $P$. syringae pvs. aptata, atrofaciens, japonica, and syringae contained, at most, one plasmid per strain.

Genomic fingerprints, based on profiles of DNA fragments generated with BOX-PCR, were similar but not identical among cantaloupe strains. For all 23 cantaloupe strains, profiles contained common fragments of about 460, 540, 820, 1,030, 1,120, and 1,425 base pairs (bp). Profiles are shown in Figure 2A for 18 strains. The remaining five strains not shown in this figure had profiles identical to those shown in Figure 2A. The presence or absence of the $615-, 1,210-, 1,520-$, and 1,620-bp fragments was the main variation observed among strains. There were no distinct fragments longer than 1,620 bp detected with any of the cantaloupe strains. For all reference strains of $P$. syringae pv. aptata characterized, profiles contained all of the fragments common to the cantaloupe strains and the 1,520- and 1,620-bp fragments (Fig. 2B). Furthermore, fragments longer than 1,620 bp were amplified from these strains. Reference strains of $P$. syringae pvs. atrofaciens, lapsa, and japonica varied in terms of the presence or absence of the fragment sizes characteristic of the $P$. syringae pv. aptata strains (Fig. 2B). Profiles of the reference strains of P. syringae pv. syringae were much more variable than those of the other pathovars; some contained fragment sizes not found among the other pathovars tested. Replicate BOX-PCR amplifications and gel electrophoresis were conducted at three separate dates for strains 1392, 1617, and CC94. No differences were observed in the profiles of amplified fragments among the three replicates of each of these strains.

Pathogenicity to cantaloupe and host range. Among the 23 strains of $P$. syringae isolated from cantaloupe, 10 strains consistently elicited a compatible reaction in all 11 of the cantaloupe plants that were inoculated, and 9 strains elicited a compatible reaction in 7 to 10 of the cantaloupe plants (Table 6). The remaining strains elicited reactions that were much more variable among plants, such that we could not determine if these strains were clearly virulent on cantaloupe. Among the reference strains of $P$. syringae, 3 of 5 strains of pv. aptata, 1 of 4 strains of pv. atrofaciens, and 3 of 17 strains of pv. syringae elicited compatible reactions in 7 to 11 of the inoculated cantaloupe plants (Table 6). Alternatively, no compatible reactions were elicited in cantaloupe by any of the strains of $P$. syringae pvs. antirrhini, cannabina, garcae, lachrymans, papulans, and pisi, or by 1 of 5 strains of pv. aptata, 2 of 4 strains of pv. atrofaciens, or 9 of 17 strains of pv. syringae. Among the strains that were not virulent on cantaloupe, strains of $P$. syringae pvs. antirrhini, cannabina, and garcae elicited mostly hypersensitive-like reactions, whereas some strains of $P$. syringae pvs. lachrymans, papulans, and pisi rarely elicited any apparent reaction. All other strains showed variable reactions, making it difficult to determine if they were virulent or not on cantaloupe.

The interaction of 46 strains of $P$. syringae from cantaloupe or from reference collections with 17 other plant species is presented in Table 7. The response of plants to inoculation was constant between the two inoculation dates for $498(63 \%)$ of the total 782 hostpathogen combinations tested (Table 7). In other words, we could

TABLE 5. Distribution of the cantaloupe strains into O-serogroups

\begin{tabular}{ll}
\hline O-serogroups $^{\text {a }}$ & \multicolumn{1}{c}{ Cantaloupe strains } \\
\hline APTPIS & CC01, CC09, CC23, CC40, CC43, CC62, CC70, \\
& CC84, CC103, CC111, CC125 \\
PERSAVTOM1 & CC73, CC88, CC94, CC145 \\
PERSAVTOM2 & CC66, CC159 \\
PERSAVTOM3 & CC101 \\
PHA/HEL1 & CC74 \\
MOP6 & CC04 \\
None & CC05, CC85, CC164 \\
\hline
\end{tabular}

a According to Saunier et al. (28).

b None of the O-serogroups of Saunier et al. (28). clearly determine if a strain was either virulent, induced a hypersensitive-like response, or induced no apparent response for $63 \%$ of the host-pathogen combinations tested. The remaining 284 combinations resulted in reactions that varied between compatible and hypersensitive-like reactions (216 combinations) or between hypersensitive-like and no reaction (68 combinations) for the two inoculation dates. Hence, for 216 combinations, we could not determine if the bacterial strain was clearly virulent, and for 68 combinations, we could not determine if the strain was clearly avirulent on the plant tested. When compatible reactions were observed, they were similar for all host-bacterium combinations: necrotic lesions
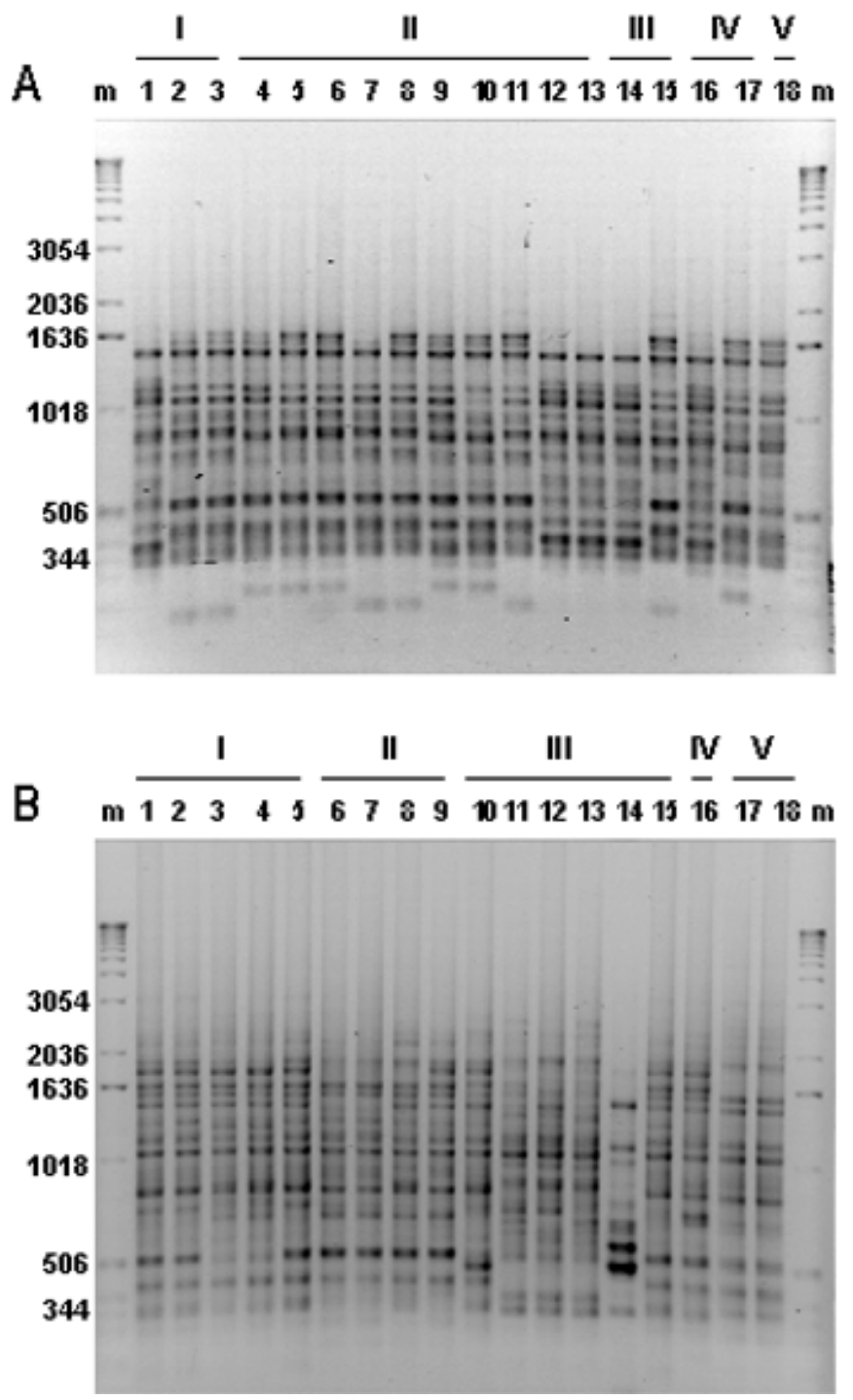

Fig. 2. BOX-polymerase chain reaction genomic DNA profiles of Pseudomonas syringae strains from $\mathbf{A}$, cantaloupe and $\mathbf{B}$, reference strains. For cantaloupe strains, a $3.5-\mu \mathrm{l}$ aliquot was loaded into each lane of $1.5 \%$ agarose gels. For reference strains, a $2.5-\mu 1$ aliquot was loaded into each lane. A, The electrophoretic patterns show strains grouped by the region from which they were isolated. Lanes 1 to 3, Lot (group I): CC73, CC111, and CC125; lanes 4 to 13, Tarn-et-Garonne (group II): CC01, CC04, CC09, CC40, CC43, CC70, CC74, CC84, CC94, and CC101; lanes 14 and 15, Gers (group III): CC66 and CC103; lanes 16 and 17, Charente-Maritime (group IV): CC159 and CC164; and lane 18, Agadir (group V): CC23. B, The patterns are shown for strains grouped by $P$. syringae pathovar. Lanes 1 to 5 , pv. aptata (group I): $1617,1906,2280,2471$, and 2507; lanes 6 to 9, pv. atrofaciens (group II): 1622, 1629, 2213, and 2256; lanes 10 to 15, pv. syringae (group III): 1392, 5B530, 9B1, B728a, 1957, and 3390; lane 16, pv. japonica (group IV): 2896; and lanes 17 and 18, pv. lapsa (group V): 1731 and 3322. A and B, The lanes labeled $\mathrm{m}$ show the DNA molecular size marker (1-kb ladder; Gibco BRL, Life Technologies SARL, Cergy Pointoise, France); the sizes are indicated in base pairs. 
TABLE 6. Reaction of cantaloupe plants to inoculation with strains of Pseudomonas syringae

\begin{tabular}{|c|c|c|c|}
\hline \multirow[b]{2}{*}{ Strain } & \multicolumn{3}{|c|}{ Number of plants in each reaction class } \\
\hline & $\begin{array}{l}\text { No reaction } \\
(0)^{\mathrm{a}}\end{array}$ & $\begin{array}{c}\text { Hypersensitive-like } \\
\text { (1) }\end{array}$ & $\begin{array}{l}\text { Compatible } \\
\qquad(2+3)\end{array}$ \\
\hline \multicolumn{4}{|l|}{ Strains from cantaloupe } \\
\hline CC09 & 0 & 0 & 11 \\
\hline $\mathrm{CC} 40$ & 0 & 0 & 11 \\
\hline CC62 & 0 & 0 & 11 \\
\hline $\mathrm{CC} 70$ & 0 & 0 & 11 \\
\hline $\mathrm{CC} 73$ & 0 & 0 & 11 \\
\hline CC84 & 0 & 0 & 11 \\
\hline CC88 & 0 & 0 & 11 \\
\hline CC94 & 0 & 0 & 11 \\
\hline $\mathrm{CC} 125$ & 0 & 0 & 11 \\
\hline CC164 & 0 & 0 & 11 \\
\hline $\mathrm{CC} 04$ & 0 & 1 & 10 \\
\hline $\mathrm{CC} 145$ & 0 & 1 & 10 \\
\hline $\mathrm{CC} 159$ & 0 & 1 & 10 \\
\hline $\mathrm{CC} 74$ & 0 & 2 & 9 \\
\hline $\mathrm{CC} 101$ & 0 & 2 & 9 \\
\hline $\mathrm{CC} 01$ & 1 & 2 & 8 \\
\hline CC103 & 0 & 3 & 8 \\
\hline CC111 & 0 & 3 & 8 \\
\hline CC66 & 0 & 4 & 7 \\
\hline $\mathrm{CC} 23$ & 1 & 6 & 4 \\
\hline $\mathrm{CC} 85$ & 0 & 7 & 4 \\
\hline $\mathrm{CC} 43$ & 1 & 6 & 4 \\
\hline $\mathrm{CC} 05$ & 0 & 8 & 3 \\
\hline \multicolumn{4}{|l|}{ Reference strains } \\
\hline pv. antirrhini $1620 * * b$ & 0 & 6 & 0 \\
\hline pv. antirrhini $1723 * *$ & 0 & 6 & 0 \\
\hline pv. antirrhini $3715^{* *}$ & 1 & 5 & 0 \\
\hline pv. aptata 1906 & 0 & 0 & 11 \\
\hline pv. aptata 1617 & 1 & 0 & 11 \\
\hline pv. aptata 2280 & 0 & 2 & 9 \\
\hline pv. aptata 2507 & 0 & 7 & 4 \\
\hline pv. aptata 2471 & 0 & 11 & 0 \\
\hline pv. atrofaciens 2213 & 0 & 2 & 9 \\
\hline pv. atrofaciens 2256 & 0 & 9 & 2 \\
\hline pv. atrofaciens 1622 & 0 & 11 & 0 \\
\hline pv. atrofaciens $1629 * *$ & 0 & 6 & 0 \\
\hline pv. cannabina 2341 & 0 & 11 & 0 \\
\hline pv. garcae 1634 & 2 & 9 & 0 \\
\hline pv. japonica 2896 & 0 & 8 & 3 \\
\hline pv. lachrymans 70 & 0 & 11 & 0 \\
\hline pv. lachrymans 2104 & 0 & 11 & 0 \\
\hline pv. lachrymans 5823 & 10 & 1 & 0 \\
\hline pv. lachrymans 7501 & 10 & 1 & 0 \\
\hline pv. lapsa $1731 * *$ & 0 & 3 & 3 \\
\hline pv. lapsa $3322 * *$ & 0 & 4 & 2 \\
\hline pv. papulans $1748 * *$ & 2 & 4 & 0 \\
\hline pv. papulans $1754 * *$ & 2 & 4 & 0 \\
\hline pv. papulans $3326 * *$ & 3 & 3 & 0 \\
\hline pv. pisi 1436 & 10 & 1 & 0 \\
\hline pv. pisi 2258 & 1 & 10 & 0 \\
\hline pv. syringae $9 \mathrm{~b} 1$ & 0 & 0 & 11 \\
\hline pv. syringae 1392 & 0 & 1 & 10 \\
\hline pv. syringae 3390 & 0 & 4 & 7 \\
\hline pv. syringae 5B530 & 0 & 6 & 5 \\
\hline pv. syringae $\mathrm{B} 728 \mathrm{a}$ & 0 & 8 & 3 \\
\hline pv. syringae 1957 & 3 & 0 & 3 \\
\hline pv. syringae $1779 * *$ & 0 & 4 & 2 \\
\hline pv. syringae 1788 & 0 & 10 & 1 \\
\hline pv. syringae $1583^{* *}$ & 0 & 6 & 0 \\
\hline pv. syringae $1679 * *$ & 0 & 6 & 0 \\
\hline pv. syringae $1693^{* *}$ & 0 & 6 & 0 \\
\hline pv. syringae $1019 * *$ & 1 & 5 & 0 \\
\hline pv. syringae $1608 * *$ & 1 & 5 & 0 \\
\hline pv. syringae $1734^{* *}$ & 1 & 5 & 0 \\
\hline pv. syringae $1778 * *$ & 4 & 2 & 0 \\
\hline pv. syringae $2236^{* *} *$ & 4 & 2 & 0 \\
\hline pv. syringae 1780 & 9 & 2 & 0 \\
\hline
\end{tabular}

${ }^{\mathrm{a}}$ Numbers in parentheses indicate the reaction of the plant scored at 2 and 7 days after inoculation: $0=$ no obvious symptoms; $1=$ hypersensitive-like reaction localized at the point of inoculation; $2=$ slight expansion of a necrotic zone of tissue away from the point of inoculation, necrosis and breaking of the petiole, or both; and $3=$ expansion of a necrotic zone of tissue away from the point of inoculation, leading to death of the entire leaf or the entire plant.

${ }^{\mathrm{b}}$ Strains marked with $* *$ were inoculated onto six cantaloupe plants. All other strains were inoculated onto 11 cantaloupe plants. developed at the point of inoculation leading to collapse and death of the laminar and petiole tissue adjacent to the point of inoculation. In addition, some strains caused systemic symptoms leading to necrosis of the entire leaf blade or the whole plant.

Host range varied considerably among bacterial strains, comprising up to 10 susceptible plant species per strain. No strains were virulent on oats, wheat, or Chinese cabbage (Table 7). Onion and sugar beet were the species most frequently within the host range of the bacterial strains tested. Most strains of $P$. syringae virulent on cantaloupe were also virulent on onion (14 of 19 strains from cantaloupe and 6 of 7 reference strains) and on sugar beet (14 of 19 strains from cantaloupe and 5 of 7 reference strains) (Fig. 3). Virulence on onion was observed in five strains that were not virulent on cantaloupe (CC23 and reference strains 1622, 2256, 2471, and B728a) (Table 7). However, virulence to sugar beet was limited to only those strains that were virulent on cantaloupe. Furthermore, virulence to both onion and sugar beet was observed in 11 of 19 strains of $P$. syringae from cantaloupe and in 3 of 3 strains of $P$. syringae pv. aptata and 1 strain of $P$. syringae pv. syringae (9B1) virulent on cantaloupe (Fig. 3).

The host range of strains that were not virulent on cantaloupe was much more limited than that of strains virulent on cantaloupe. Among the 20 strains that were not pathogenic to cantaloupe, 10 were virulent on only one to three other plant species and 10 were not virulent on any of the plants tested (Table 7). However, all these latter 10 strains elicited a hypersensitive response in tobacco, in some of the 17 plant species tested, or in some combination of tobacco and other plant species tested.

The extent of the host range of a given bacterial strain was correlated with the aggressiveness of the strain on cantaloupe. The strains that were most aggressive on cantaloupe attacked the greatest number of plant species, whereas the strains least aggressive on cantaloupe had the most limited host range (Fig. 4). The most aggressive strains with the broadest host range (at least nine plant species) were strains CC40, CC62, CC88, CC125, CC145, 1906, and 9B1.

\section{DISCUSSION}

The identification of strains of $P$. syringae at the pathovar level poses serious practical problems. Much effort has been invested in finding biochemical or genotypic markers for pathovars so as to avoid the need for host range tests, but most of these markers have limited utility. Biochemical tests can differentiate clusters that include several, very closely related pathovars (40). For example, $P$. syringae pvs. aptata, atrofaciens, dysoxyli, japonica, and syringae cannot be easily separated based on biochemical tests. Fatty acid profiles of pathovars have been studied and may give inaccurate results; only $33 \%$ of $P$. syringae pv. atrofaciens strains and $12 \%$ of P. syringae pv. syringae strains were correctly identified with this method (33). Identification of pathovars via serotyping has been accomplished with monoclonal (25) and polyclonal (28) antibodies. However, some pathovars have identical serological profiles. Nutrient utilization profiles, such as those generated with the Biolog system, are also unreliable for certain pathovars of $P$. syringae (14). The reliability of identification based on genomic profiles from PCR amplification of repetitive elements depends on the pathovar. For example, strains of $P$. syringae pv. morsprunorum have identical REP-, ERIC-, and BOX-PCR profiles (20) and strains of $P$. syringae pv. glycinea have very similar REP-, ERIC-, and IS50-PCR profiles (37). However, in the same studies, strains within $P$. syringae pvs. aptata, atrofaciens, syringae, and tomato did not have uniform profiles $(20,37)$. Identification of pathovars with oligonucleotide primers for PCR amplification of specific sequences is promising $(2,3,26,34)$, but this approach is currently limited to only a few pathovars.

The search for tests to differentiate pathovars is based on the assumption that a pathovar is a physiologically and genetically homo- 
genous taxonomic unit. Given the limits of the various phenotypic and genotypic markers cited above, and the possibility of horizontal transfer of genetic factors implicated in pathogenicity (7), this assumption is probably not universally valid. For example, the work of Vauterin and Swings (35) illustrates the difficulty in conciliating the host range- and genotype-based classifications for Xanthomonas spp. It should also be noted that a possible complicating factor in the search for these markers is that the identification of the reference strains employed in such studies may not always be correct. The pathogenicity of strains on a standard set of host plants is rarely verified. Identifying pathovars by characterizing host range corresponds to the definition of pathovar sensu stricto. Furthermore, this approach yields pertinent epidemiological information. However, there are major obstacles to host range tests that may explain why they are rarely used for identification of pathovars of $P$. syringae. Probably the most important obstacle is that no standard set of host plants for differentiating pathovars of $P$. syringae has been proposed. Here, we used host plants that had the potential to differentiate among pathovars that are biochemically and physiologically similar to $P$. syringae pv. syringae based on host ranges reported by Bradbury (6). A second significant obstacle is the difficulty of interpreting results. The host response may be variable among the individual plants inoculated with a given strain, which complicates the comparison of host range among strains. When cultivars are employed that are not homogenous for the genes involved in the host-pathogen interaction, this variability may be particularly important.

Based on the results of biochemical tests, serotyping, and syringomycin production assays, the strains of $P$. syringae causing cantaloupe blight in France closely resemble strains of $P$. syringae pvs. aptata, atrofaciens, japonica, lapsa, and syringae. In BOX-PCR profiles, the cantaloupe strains also share many bands in common with profiles of strains of these five pathovars, but they are not identical to any of them. Although these tests helped to eliminate some pathovars as possible identifications of the cantaloupe strains, none of them help us to clearly distinguish among these five pathovars.

Based on results of host range tests, we propose that the population of bacteria responsible for cantaloupe blight in France is com-

TABLE 7. The interaction of strains of Pseudomonas syringae with 17 plant species at two inoculation dates

\begin{tabular}{|c|c|c|c|c|c|c|c|c|c|c|c|c|c|c|c|c|c|c|}
\hline $\begin{array}{l}\text { Origin or } \\
\text { pathovar }^{b}\end{array}$ & Strain & Barley & Bean & $\begin{array}{l}\text { Chinese } \\
\text { cabbage }\end{array}$ & Corn & Cucumber & $\begin{array}{l}\text { Egg- } \\
\text { plant }\end{array}$ & Lettuce & Oats & Onion & Pea & Pepper & Sorghum & $\begin{array}{l}\text { Soy- } \\
\text { bean }\end{array}$ & $\begin{array}{c}\text { Sugar } \\
\text { beet }\end{array}$ & $\begin{array}{c}\text { Sun- } \\
\text { flower }\end{array}$ & Tomato & Wheat \\
\hline \multirow[t]{22}{*}{ Cantaloupe } & $\mathrm{CC} 01$ & HR & HR & HR & HR & V1 & V1 & HR & V1 & V1 & V1 & HR & HR & HR & V1 & HR & $\mathrm{P}$ & V1 \\
\hline & $\mathrm{CC} 04$ & HR & V1 & HR & V1 & V1 & $\mathrm{P}$ & $\mathrm{P}$ & V1 & $\mathrm{P}$ & $\mathrm{P}$ & V1 & V1 & $\mathrm{P}$ & $\mathrm{P}$ & $\mathrm{P}$ & V1 & V1 \\
\hline & $\mathrm{CC} 09$ & $\mathrm{P}$ & $\mathrm{P}$ & HR & $\mathrm{P}$ & V1 & $\mathrm{P}$ & HR & HR & V1 & V1 & HR & HR & $\mathrm{P}$ & $\mathrm{P}$ & V1 & V1 & HR \\
\hline & $\mathrm{CC} 23$ & $\mathrm{~V} 2$ & HR & HR & HR & HR & V1 & HR & $\mathrm{V} 2$ & $\mathrm{P}$ & V1 & HR & HR & HR & V1 & HR & V1 & $\mathrm{V} 2$ \\
\hline & $\mathrm{CC} 40$ & V1 & $\mathrm{P}$ & HR & $\mathrm{P}$ & V1 & $\mathrm{P}$ & $\mathrm{P}$ & V1 & $\mathrm{P}$ & V1 & $\mathrm{P}$ & $\mathrm{P}$ & HR & $\mathrm{P}$ & $\mathrm{P}$ & $\mathrm{P}$ & $\mathrm{V} 2$ \\
\hline & $\mathrm{CC} 43$ & HR & HR & HR & HR & HR & HR & HR & $\mathrm{V} 2$ & HR & V1 & HR & HR & HR & HR & HR & V1 & HR \\
\hline & CC62 & HR & $\mathrm{P}$ & V1 & V1 & $\mathrm{P}$ & V1 & $\mathrm{P}$ & V1 & $\mathrm{P}$ & $\mathrm{P}$ & $\mathrm{P}$ & $\mathrm{P}$ & V1 & $\mathrm{P}$ & $\mathrm{P}$ & $\mathrm{P}$ & V1 \\
\hline & CC66 & HR & HR & HR & HR & V1 & V1 & V1 & $\mathrm{V} 2$ & $\mathrm{P}$ & $\mathrm{P}$ & $\mathrm{P}$ & HR & HR & V1 & V1 & $\mathrm{P}$ & $\mathrm{V} 2$ \\
\hline & CC70 & HR & $\mathrm{P}$ & V1 & $\mathrm{P}$ & V1 & V1 & V1 & V1 & $\mathrm{P}$ & $\mathrm{P}$ & HR & V1 & V1 & $\mathrm{P}$ & $\mathrm{P}$ & V1 & V1 \\
\hline & $\mathrm{CC} 73$ & HR & HR & V1 & V1 & V1 & $\mathrm{P}$ & $\mathrm{P}$ & HR & $\mathrm{P}$ & $\mathrm{P}$ & $\mathrm{P}$ & HR & HR & $\mathrm{P}$ & $\mathrm{P}$ & $\mathrm{P}$ & HR \\
\hline & CC74 & HR & HR & HR & $\mathrm{P}$ & V1 & VI & HR & V1 & $\mathrm{P}$ & V1 & HR & V1 & V1 & $\mathrm{P}$ & V1 & HR & V2 \\
\hline & CC84 & HR & V1 & HR & V1 & V1 & $\mathrm{P}$ & V1 & $\mathrm{V} 2$ & $\mathrm{P}$ & V1 & $\mathrm{P}$ & V1 & V1 & $\mathrm{P}$ & $\mathrm{P}$ & V1 & $\mathrm{V} 2$ \\
\hline & CC85 & $\mathrm{V} 2$ & HR & HR & HR & $\mathrm{V} 2$ & V1 & HR & V1 & HR & V1 & HR & HR & V1 & V1 & HR & HR & V1 \\
\hline & CC88 & HR & V1 & HR & $\mathrm{P}$ & V1 & $\mathrm{P}$ & $\mathrm{P}$ & V1 & V1 & $\mathrm{P}$ & $\mathrm{P}$ & HR & $\mathrm{P}$ & $\mathrm{P}$ & $\mathrm{P}$ & $\mathrm{P}$ & HR \\
\hline & СС94 & HR & $\mathrm{P}$ & HR & V1 & V1 & V1 & V1 & V1 & $\mathrm{P}$ & $\mathrm{P}$ & $\mathrm{P}$ & HR & V1 & $\mathrm{P}$ & $\mathrm{P}$ & $\mathrm{P}$ & V2 \\
\hline & CC101 & HR & V1 & HR & HR & V1 & $\mathrm{P}$ & V1 & HR & V1 & $\mathrm{P}$ & $\mathrm{P}$ & V1 & V1 & V1 & $\mathrm{P}$ & V1 & V2 \\
\hline & $\mathrm{CC} 103$ & V1 & HR & HR & V1 & V1 & HR & V1 & V1 & $\mathrm{P}$ & V1 & V1 & V1 & HR & V1 & V1 & $\mathrm{P}$ & V1 \\
\hline & CC111 & HR & HR & HR & V1 & V1 & V1 & HR & $\mathrm{V} 2$ & $\mathrm{P}$ & $\mathrm{P}$ & $\mathrm{P}$ & V1 & V1 & HR & $\mathrm{P}$ & HR & 0 \\
\hline & $\mathrm{CC} 125$ & $\mathrm{P}$ & V1 & V1 & $\mathrm{P}$ & V1 & $\mathrm{P}$ & $\mathrm{P}$ & V2 & $\mathrm{P}$ & $\mathrm{P}$ & $\mathrm{P}$ & V1 & $\mathrm{P}$ & $\mathrm{P}$ & $\mathrm{P}$ & V1 & HR \\
\hline & CC145 & $\mathrm{P}$ & $\mathrm{P}$ & HR & V1 & HR & $\mathrm{P}$ & $\mathrm{P}$ & V1 & $\mathrm{P}$ & $\mathrm{P}$ & $\mathrm{P}$ & V1 & HR & $\mathrm{P}$ & $\mathrm{P}$ & V1 & V2 \\
\hline & CC159 & HR & HR & HR & V1 & $\mathrm{P}$ & V1 & $\mathrm{P}$ & $\mathrm{V} 2$ & $\mathrm{P}$ & V1 & $\mathrm{P}$ & V1 & V1 & $\mathrm{P}$ & $\mathrm{P}$ & $\mathrm{P}$ & V2 \\
\hline & CC164 & V1 & HR & HR & HR & HR & $\mathrm{P}$ & V1 & $\mathrm{V} 2$ & V1 & $\mathrm{HR}$ & HR & HR & HR & $\mathrm{P}$ & V1 & V1 & V2 \\
\hline \multirow[t]{5}{*}{ pv. aptata } & 1617 & HR & V1 & V2 & HR & V1 & HR & V1 & V1 & $\mathrm{P}$ & V1 & HR & V1 & V1 & $\mathrm{P}$ & HR & V1 & V1 \\
\hline & 1906 & HR & V1 & HR & $\mathrm{P}$ & $\mathrm{P}$ & $\mathrm{P}$ & $\mathrm{P}$ & V1 & $\mathrm{P}$ & V1 & $\mathrm{P}$ & V1 & V1 & $\mathrm{P}$ & $\mathrm{P}$ & $\mathrm{P}$ & V1 \\
\hline & 2280 & $\mathrm{P}$ & HR & HR & V1 & $\mathrm{P}$ & V1 & V1 & V1 & $\mathrm{P}$ & V1 & $\mathrm{P}$ & V1 & V1 & $\mathrm{P}$ & V1 & HR & V1 \\
\hline & 2471 & HR & HR & HR & V1 & HR & V1 & HR & HR & $\mathrm{P}$ & $\mathrm{P}$ & HR & V1 & V1 & V1 & $\mathrm{HR}$ & HR & V2 \\
\hline & 2507 & HR & V1 & HR & V1 & HR & $\mathrm{P}$ & HR & $\mathrm{V} 2$ & HR & $\mathrm{P}$ & HR & HR & HR & V1 & $\mathrm{HR}$ & HR & HR \\
\hline \multirow[t]{3}{*}{ pv. atrofaciens } & 1622 & HR & HR & HR & HR & HR & V1 & $\mathrm{V} 2$ & V1 & $\mathrm{P}$ & V1 & HR & HR & HR & V1 & HR & HR & V1 \\
\hline & 2213 & HR & HR & HR & V1 & HR & HR & HR & V1 & V1 & V1 & HR & V1 & HR & $\mathrm{P}$ & V1 & HR & $\mathrm{V} 2$ \\
\hline & 2256 & $\mathrm{~V} 2$ & HR & V1 & V1 & HR & HR & HR & HR & $\mathrm{P}$ & $\mathrm{P}$ & HR & $\mathrm{P}$ & HR & HR & HR & V1 & HR \\
\hline pv. cannabina & 2341 & HR & HR & HR & HR & HR & HR & HR & $\mathrm{V} 2$ & HR & V1 & HR & HR & HR & HR & HR & V1 & $\mathrm{V} 2$ \\
\hline pv. garcae & 1634 & HR & HR & HR & $\mathrm{V} 2$ & 0 & HR & HR & HR & V1 & V1 & HR & HR & HR & HR & HR & HR & $\mathrm{V} 2$ \\
\hline pv. japonica & 2896 & HR & HR & HR & HR & HR & $\mathrm{P}$ & V1 & V1 & V1 & V1 & V1 & V1 & HR & V1 & HR & HR & V1 \\
\hline \multirow[t]{4}{*}{ pv. lachrymans } & 70 & $\mathrm{~V} 2$ & HR & HR & HR & HR & HR & HR & HR & HR & $\mathrm{P}$ & HR & HR & HR & HR & $\mathrm{HR}$ & HR & HR \\
\hline & 2104 & HR & HR & HR & HR & HR & HR & HR & HR & HR & V1 & HR & HR & HR & HR & HR & HR & 0 \\
\hline & 5823 & 0 & $\mathrm{~V} 2$ & $\mathrm{~V} 2$ & 0 & 0 & 0 & $\mathrm{~V} 2$ & $\mathrm{~V} 2$ & 0 & 0 & $\mathrm{~V} 2$ & $\mathrm{~V} 2$ & $\mathrm{~V} 2$ & 0 & 0 & $\mathrm{~V} 2$ & 0 \\
\hline & 7501 & 0 & 0 & $\mathrm{~V} 2$ & HR & 0 & 0 & $\mathrm{~V} 2$ & 0 & HR & $\mathrm{HR}$ & HR & $\mathrm{V} 2$ & $\mathrm{~V} 2$ & 0 & V1 & 0 & 0 \\
\hline \multirow[t]{2}{*}{ pv.pisi } & 1436 & $\mathrm{~V} 2$ & 0 & 0 & $\mathrm{~V} 2$ & 0 & 0 & $\mathrm{~V} 2$ & 0 & HR & $\mathrm{HR}$ & HR & HR & $\mathrm{HR}$ & $\mathrm{V} 2$ & $\mathrm{~V} 2$ & 0 & $\mathrm{~V} 2$ \\
\hline & 2258 & $\mathrm{~V} 2$ & HR & $\mathrm{V} 2$ & HR & HR & HR & HR & V1 & V2 & $\mathrm{P}$ & HR & HR & HR & HR & $\mathrm{HR}$ & HR & V2 \\
\hline \multirow[t]{7}{*}{ pv. syringae } & $5 B 530$ & V2 & HR & HR & $\mathrm{V} 2$ & V1 & $\mathrm{P}$ & HR & V2 & V1 & V1 & $\mathrm{P}$ & HR & HR & V1 & V1 & HR & $\mathrm{V} 2$ \\
\hline & B728a & $\mathrm{V} 2$ & HR & HR & HR & HR & V1 & HR & V2 & $\mathrm{P}$ & V1 & V1 & HR & HR & HR & HR & V1 & $\mathrm{V} 2$ \\
\hline & 9B1 & HR & $\mathrm{P}$ & HR & HR & V1 & $\mathrm{P}$ & $\mathrm{P}$ & V1 & $\mathrm{P}$ & $\mathrm{P}$ & $\mathrm{P}$ & HR & HR & $\mathrm{P}$ & $\mathrm{P}$ & $\mathrm{P}$ & V1 \\
\hline & 1392 & HR & HR & HR & HR & HR & $\mathrm{P}$ & HR & V1 & $\mathrm{P}$ & V1 & $\mathrm{P}$ & HR & HR & V1 & HR & V1 & $\mathrm{V} 2$ \\
\hline & 1780 & 0 & 0 & 0 & 0 & V1 & 0 & 0 & V2 & 0 & 0 & 0 & $\mathrm{~V} 2$ & HR & $\mathrm{V} 2$ & V2 & 0 & 0 \\
\hline & 1788 & HR & HR & HR & V1 & HR & HR & HR & $\mathrm{V} 2$ & V1 & V1 & HR & HR & HR & HR & HR & V1 & $\mathrm{V} 2$ \\
\hline & 3390 & $\mathrm{P}$ & V1 & HR & V1 & V1 & HR & HR & HR & $\mathrm{P}$ & $\mathrm{P}$ & HR & $\mathrm{P}$ & V1 & V1 & V1 & V1 & HR \\
\hline
\end{tabular}

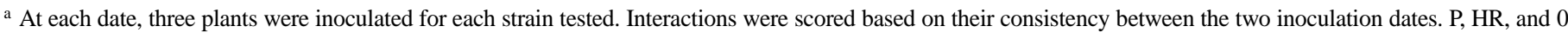
indicate that compatible reactions, hypersensitive-like reactions, and no apparent reaction, respectively, were observed in at least two of three plants at both inoculation dates. V1 indicates that compatible reactions were observed in at least two of three plants at one date, but that hypersensitive-like reactions were observed in most plants at the other date. V2 indicates that most plants showed hypersensitive-like reactions at one date, but no apparent reaction at the other date.

b Pseudomonas syringae pathovars.
} 
posed principally of strains virulent on sugar beet. All strains that were virulent on sugar beet in this study were also virulent on cantaloupe. Furthermore, 25 of the 26 strains virulent on cantaloupe elicited compatible reactions in sugar beet. For 19 of these strains, the expression of virulence on sugar beet was consistent among the two inoculation dates; for six strains, compatible reactions were induced, but not consistently, between the two inoculation dates. Virulence on cantaloupe was best correlated to that on sugar beet when compared with all other hosts tested. Although most strains that were pathogenic to cantaloupe were also virulent on onion, five strains that were not pathogenic to cantaloupe were clearly virulent on onion. Hence, we propose that the strains causing cantaloupe blight should be considered $P$. syringae pv. aptata.

Host ranges were highly variable among the strains characterized in this study. No strains had the same host range. Furthermore, the number of plant species attacked was not characteristic of any particular group of strains or of any pathovar. Host range tended to increase with increasing aggressiveness on cantaloupe. This result suggests why there may be confusion between the concepts of virulence and aggressiveness in phytobacteriology. As pointed out by Andrivon (1) in the debate published in Phytopathology about the definition of these terms, virulence is a qualitative trait reflecting whether a pathogenic strain can or cannot cause disease on a given host. Aggressiveness, on the other hand, designates the quantity of disease induced by a pathogenic strain on a susceptible host. In the case of the pathogenicity tests conducted here, it might be possible that strains needed to be sufficiently aggressive to induce a reaction in the plant that we could detect as a

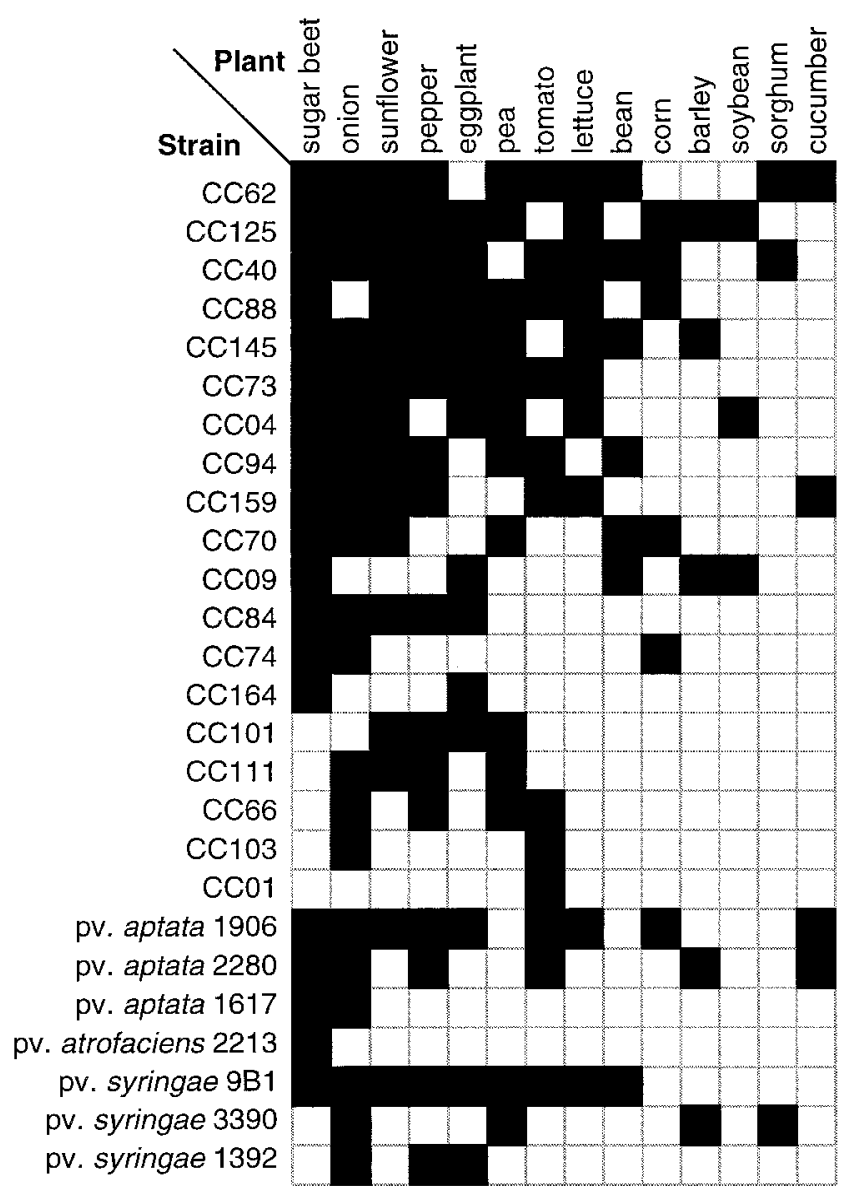

Fig. 3. Host range of strains of Pseudomonas syringae pathogenic on cantaloupe. Solid black squares indicate a compatible reaction between the host and the strain for at least two of three inoculated plants at both inoculation dates. A total of 17 plant species was inoculated; results for three of these (Chinese cabbage, wheat, and oats) are not presented, because compatible reactions were not consistently observed at both inoculation dates for any of the strains tested. compatible interaction. Hence, some of the hypersensitive-like reactions observed may have been weak compatible interactions. This would suggest that the host range of some of the strains studied here is larger than what we report. Furthermore, the relationship we observed between aggressiveness and virulence suggests an important linkage of the genes implicated in these processes or an intimate interaction of the gene products involved.

Our work illustrates the utility of using host range tests for the identification of strains of $P$. syringae. However, it also illustrates some of the difficulties that need to be resolved before host range testing can effectively contribute to the taxonomy and identification of $P$. syringae strains on a routine basis. For example, several reference strains used here did not incite compatible reactions on their host of origin. This may have been because the cultivars that we used were resistant or tolerant to these strains or because these strains had lost the necessary virulence factors. Secondly, several of the plant species inoculated (Chinese cabbage, oats, and wheat) never showed any consistent compatible reactions. Although it is possible that none of the strains we used were virulent on these plants, it may also suggest that these plants were either difficult to inoculate or that we were not able to recognize compatible reactions for these plants. The choice of plant species and cultivars, of virulent reference strains, and of inoculation methods adapted to each of these hosts will require considerable effort but is essential for establishing of a set of differential plant species for identifying pathovars of $P$. syringae.

This is the first report of $P$. syringae pv. aptata as a pathogen of $C$. melo under field conditions. The only other previous report of virulence of $P$. syringae pv. aptata to $C$. melo of which we are aware is based on inoculation of slices of cantaloupe fruits (38). However, in light of the problems mentioned above for the identification of pathovars, it is not unlikely that $P$. syringae pv. aptata is the causal agent of other bacterial blights of melon reported to be caused by diverse pathovars of $P$. syringae. In previous reports of $P$. syringae as a pathogen of melons, host range studies were either omitted or were limited to cucurbit species. For strains of $P$. syringae isolated from diseased honeydew from Colorado in the 1940s (31), pathogenicity was confirmed on honeydew and cucumbers only. In the first reports of bacterial blight of field-produced cantaloupe in France (22), the bacterium was referred to as $P$. syringae pv. lachrymans, because it infected a cucurbit. It was assumed to be the same pathogen that causes angular leaf spot of cucumber. This same assumption has also been made for a bacterial blight of melon observed in California (information available on-line from the Statewide Integrated Pest Management Project, University of California, Davis).

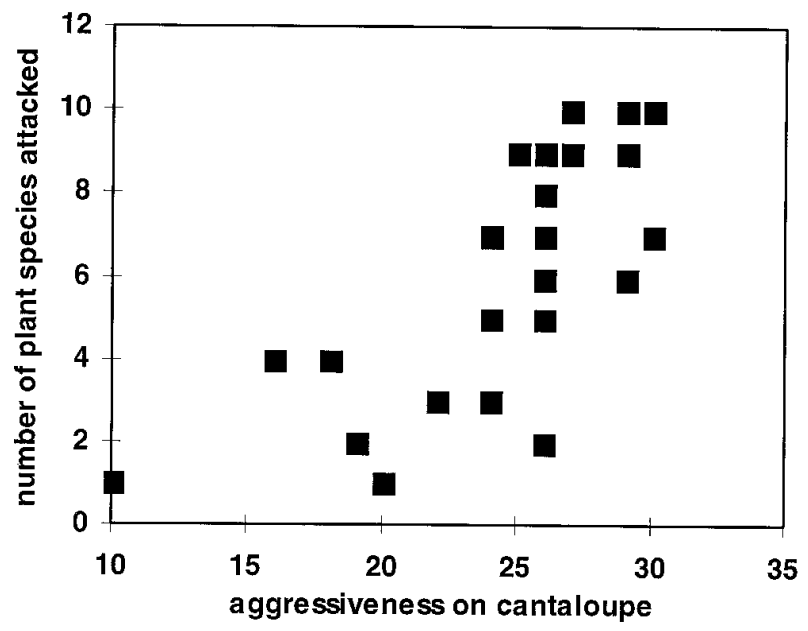

Fig. 4. The relationship between the aggressiveness of strains on cantaloupe and the number of other plant species on which the strains were virulent. The aggressiveness of each strain is expressed as the sum of disease severity ratings for compatible reactions (disease scores 2 or 3 ) for the 11 cantaloupe plants inoculated. The strains and plant species represented are those presented in Figure 3. 
Although bacterial blight of melons caused by $P$. syringae pv. aptata may occur elsewhere in the world, currently, it seems to be causing significant losses only in France. We suggest that the following factors have contributed to this apparent particularity. First, it should be noted that southwestern France was the site of the severe epidemics that first attracted our attention to the importance of this disease. This region of France is also a major site for sugar beet seed production from which strains of $P$. syringae pv. aptata have been recently isolated (21). These production areas may have produced inoculum for nearby cantaloupes. During the cantaloupe production seasons in southwestern France from 1993 to 1997, the climate was particularly favorable for the development of severe bacterial blights. During the production season in each of these years, there were at least one or two heavy storms (with at least $30 \mathrm{~mm}$ of rain per rain event) followed by several days of cool, rainy weather. Some production zones recorded the heaviest rains observed in the past 30 years. Hence, these circumstances led us to distinguish the symptoms of this disease from those caused by Cladosporium cucumerinum and Colletotrichum spp. (5), and we were able to repeatedly isolate the pathogen during several seasons of production. The identification of the causal agent of bacterial blight of cantaloupe as $P$. syringae pv. aptata has allowed us to hypothesize this scenario. We are currently searching for sources of inoculum and conducting detailed studies of the geographic distribution and structure of the populations of this pathogen. Furthermore, we are investigating the possibility that the cultivars of cantaloupe adapted to French production conditions may be particularly sensitive to this disease and may be a contributing factor to its importance in France.

\section{ACKNOWLEDGMENTS}

We thank S. Hirano of the University of Wisconsin and J. Young of Landcare Research New Zealand Ltd. for the generous donations of strains.

\section{LITERATURE CITED}

1. Andrivon, D. 1993. Nomenclature for pathogenicity and virulence: The need for precision. Phytopathology 83:889-890.

2. Arnold, D. L., Athey-Pollard, A., Gibbon, M. J., Taylor, J. D., and Vivian, A. 1996. Specific oligonucleotide primers for the identification of Pseudomonas syringae pv. pisi yield one of two possible DNA fragments by PCR amplification: Evidence for phylogenetic divergence. Physiol. Mol. Plant Pathol. 49:233-245.

3. Bereswill, S., Bugert, P., Völksch, B., Ullrich, M., Bender, C. L., and Geider, K. 1994. Identification and relatedness of coronatine-producing Pseudomonas syringae pathovars by PCR analysis and sequence determination of the amplified products. Appl. Environ. Microbiol. 60:29242930.

4. Blancard, D., Lecoq, H., and Pitrat, M. 1991. Maladies des Cucurbitacées: Observer, identifier, lutter. PHM Revue Horticle, Limoges and INRA, Paris

5. Blancard, D., and Morris, C. E. 1998. Quel est votre diagnostic? PHM Rev. Hortic. 391:57-58.

6. Bradbury, J. F. 1986. Guide to Plant Pathogenic Bacteria. CAB International Mycological Institute, Kew, Surrey, England.

7. Gabriel, D. W. 1999. Why do pathogens carry avirulence genes? Physiol. Mol. Plant Pathol. 55:205-214.

8. Gardan, L., Bollet, C., Ghorrah, M. A., Grimont, F., and Grimont, P. A. D. 1992. DNA relatedness among the pathovar strains of Pseudomonas syringae subsp. savastanoi Janse (1982) and proposal of Pseudomonas savastanoi sp. nov. Int. J. Syst. Bacteriol. 42:606-612.

9. Goumas, D. E., and Chatzaki, A. K. 1998. Characterization and host range evaluation of Pseudomonas viridiflava from melon, blite, tomato, chrysanthemum and eggplant. Eur. J. Plant Pathol. 104:181-188.

10. Gross, D. C. 1985. Regulation of syringomycin synthesis in Pseudomonas syringae pv. syringae and defined conditions for its production. J. Appl. Bacteriol. 58:167-174.

11. Gross, D. C., and DeVay, J. E. 1977. Population dynamics and pathogenesis of Pseudomonas syringae in maize and cowpea in relation to the in vitro production of syringomycin. Phytopathology 67:475-483.

12. Hildebrand, D. C. 1971. Pectate and pectin gels for differentiation of Pseudomonas sp. and other bacterial plant pathogens. Phytopathology
61:1430-1436.

13. Isakeit, T., Black, M. C., Barnes, L. W., and Jones, J. B. 1997. First report of infection of honeydew with Acidovorax avenae subsp. citrulli. Plant Dis. 81:694.

14. Jones, J. B., Chase, A. R., and Harris, G. K. 1993. Evaluation of the Biolog GN MicroPlate System for identification of some plant-pathogenic bacteria. Plant Dis. 77:553-558.

15. Kado, C. I., and Liu, S. T. 1981. A rapid procedure for detection and isolation of large and small plasmids. J. Bacteriol. 145:1365-1373.

16. King, E. O., Ward, M. K., and Raney, D. E. 1954. Two simple media for the demonstration of pyocyanin and fluorescin. J. Lab. Clin. Med. 44: 301-307.

17. Klement, Z., Farkas, G. L., and Lovrekovich, L. 1964. Hypersensitive reaction induced by phytopathogenic bacteria in the tobacco leaf. Phytopathology 54:474-477.

18. Latour, X., Corberand, T., Laguerre, G., Allard, F., and Lemanceau, P. 1996. The composition of fluorescent pseudomonad populations associated with roots is influenced by plant and soil type. Appl. Environ. Microbiol. 62:2449-2456.

19. Lelliott, R. A., Billing, E., and Hayward, A. C. 1966. A determinative scheme for the fluorescent plant pathogenic pseudomonads. J. Appl. Bacteriol. 29:470-489.

20. Louws, F. J., Fulbright, D. W., Stephens, C. T., and de Bruijn, F. J. 1994. Specific genomic fingerprints of phytopathogenic Xanthomonas and Pseudomonas pathovars and strains generated with repetitive sequences and PCR. Appl. Environ. Microbiol. 60:2286-2295.

21. Maraite, H., and Weyns, J. 1997. Pseudomonas syringae pv. aptata and pv. atrofaciens, specific pathovars or members of pv. syringae? Pages 515-520 in: Pseudomonas syringae Pathovars and Related Pathogens. K. Rudolph, T. J. Burr, J. W. Mansfield, D. Stead, A. Vivian, and J. von Kietzell, eds. Kluwer Academic Publishers, Dordrecht, the Netherlands.

22. Monnet, Y. 1995. Maladies bactériennes inféodées aux cultures légumières françaises. Phytoma Déf. Végét. 468:36-38.

23. Morris, C. E., and Pitrat, M. 1998. La bactériose du melon: Connaissances acquises et travaux en cours. PHM Rev. Hortic. 393:44-47.

24. Neto, J. R., Sugimori, M. H., and Oliveira, A. R. 1984. A bacterial rot of muskmelon (Cucumis melo L.) caused by Xanthomonas campestris pv. melonis pv. nov. Summa Phytopathol. 10:217-233.

25. Ovod, V., Rudolph, K., and Krohn, K. 1997. Serological classification of Pseudomonas syringae pathovars based on monoclonal antibodies towards the lipopolysaccharide O-chains. Pages 526-531 in: Pseudomonas syringae Pathovars and Related Pathogens. K. Rudolph, T. J. Burr, J. W. Mansfield, D. Stead, A. Vivian, and J. von Kietzell, eds. Kluwer Academic Publishers, Dordrecht, the Netherlands.

26. Prosen, D., Hatziloukas, E., Schaad, N. W., and Panopoulos, N. J. 1993. Specific detection of Pseudomonas syringae pv. phaseolicola DNA in bean seed by polymerase chain reaction-based amplification of a phaseolotoxin gene region. Phytopathology 83:965-970.

27. Prunier, J. P., and Kaiser, P. 1961. Etude de l'activité pectinolytique chez des bactéries phytopathogènes et saprophytes des plantes. I. Recherche des enzymes pectinolytiques. Ann. Epiphyt. 15:205-219.

28. Saunier, M., Malandrin, L., and Samson, R. 1996. Distribution of Pseudomonas syringae pathovars into twenty-three O serogroups. Appl. Environ. Microbiol. 62:2360-2374.

29. Sherf, A. F., and MacNab, A. A. 1986. Cucurbits. Pages 307-311 in: Vegetable Diseases and their Control. A. F. Sherf and A. A. MacNab, eds. Wiley, New York.

30. Smith, I. M., Dunez, J., Lelliott, R. A., Philipps, D. H., and Archer, S. A. 1988. European Handbook of Diseases. Blackwell Scientific Publications, Oxford.

31. Smith, M. A. 1946. Bacterial spot of honeydew melon. Phytopathology 36:943-949.

32. Stanier, R. Y., Palleroni, N. J., and Douderoff, N. 1966. The aerobic pseudomonads: A taxonomic study. J. Gen. Microbiol. 43:159-271.

33. Stead, D. E., Hennessy, J., Elphinstone, J. G., and Wilson, J. K. 1997. Modern methods for classification of plant pathogenic bacteria including Pseudomonas syringae. Pages 427-434 in: Pseudomonas syringae Pathovars and Related Pathogens. K. Rudolph, T. J. Burr, J. W. Mansfield, D. Stead, A. Vivian, and J. von Kietzell, eds. Kluwer Academic Publishers, Dordrecht, the Netherlands.

34. Takahashi, Y., Omura, T., Hibino, H., and Sato, M. 1996. Detection and identification of Pseudomonas syringae pv. atropurpurea by PCR amplification of specific fragments from an indigenous plasmid. Plant Dis. 80: 783-788

35. Vauterin, L., and Swings, J. 1997. Are classification and phytopathological diversity compatible in Xanthomonas. J. Indust. Microbiol. Biotechnol. 19:77-82.

36. Versalovic, J., Schneider, M., de Bruijn, F. J., and Lupski, J. R. 1994. 
Genomic fingerprinting of bacteria using repetitive sequence based (repPCR). Methods Cell. Mol. Biol. 5:25-40.

37. Weingart, H., and Völksch, B. 1997. Genetic fingerprinting of Pseudomonas syringae pathovars using ERIC-, REP-, and IS50-PCR. J. Phytopathol. 145:339-345.

38. Yarwood, C. E., Resconich, E. C., Ark, P. A., Schlegel, D. E., and Smith, K. M. 1961. So-called beet latent virus is a bacterium. Plant Dis. Rep.
45:85-89.

39. Young, J. M. 1991. Pathogenicity and identification of the lilac pathogen, Pseudomonas syringae pv. syringae van Hall 1902. Ann. Appl. Biol. 118:283-298.

40. Young, J. M., and Triggs, C. M. 1994. Evaluation of determinative tests for pathovars of Pseudomonas syringae van Hall 1902. J. Appl. Bacteriol. 77:195-207. 